\section{Frequencies of Pseudocholinesterase Variants in Icelanders, Greeks and Pakistanis}

THE formation of the human pseudocholinesterase variants is controlled by at least four alleles at one autosomal locus termed $E_{1}$ (ref. 1). The four alleles are $E_{1} u, E_{1} a, E_{1} f$ and $E_{1}{ }^{s}$ (refs. 2-5). The heterozygotes $E_{1} u E_{1} a$ have been found in remarkably uniform frequencies, about 3 to 6 per cent, in Caucasians from Europe and North America $^{3,8-11}$, and also in Australian aborigines ${ }^{12}$ and Mexican Indians ${ }^{13}$, but are relatively rare among Negroes ${ }^{11}$ and Mongoloids ${ }^{10,11,14}$. workers in the field ${ }^{8-11}$. The Pakistan series has a frequency similar to the European one. In another study ${ }^{11}$ a group of ninety-eight students from India yielded a similar result (3.1 per cent). The Icelandic series, however, is the first European population with a complete absence of the dibucaine-resistant pseudocholinesterase variant. In this respect this population resembles racially different populations, living in similar conditions: there are Alaskan Eskimos (0/145) (ref. II), another series of Alaskan Eskimos (0/122) and Athabascan Indians (0/141) (ref. 16). Further investigations should determine whether the absence of the allele $E_{1} a$ in Icelanders should be ascribed to chance or to the influence of some familial relationships or whether it is indeed typical of the population.

Table 1. FREQUENCIES OF PHENOTYPES AND GENFS FOR SERLM CHOLINESTERASE IN THE FOUR POPTLATIONS STUDIRD

\begin{tabular}{|c|c|c|c|c|c|c|c|c|c|c|c|c|}
\hline \multirow[b]{2}{*}{ Population } & \multirow[b]{2}{*}{$N$} & \multicolumn{2}{|c|}{$\mathrm{U}$} & \multicolumn{2}{|c|}{ I } & \multicolumn{2}{|c|}{$\mathrm{UF}$} & \multicolumn{2}{|c|}{ IF } & \multirow[b]{2}{*}{$E_{\mathrm{I}}{ }^{*}$} & \multirow[b]{2}{*}{$E_{1}{ }^{a}$} & \multirow[b]{2}{*}{$E_{1}^{f}$} \\
\hline & & $n$ & Per cent & $n$ & Per cent & $n$ & Per cent & $n$ & Per cent & & & \\
\hline Icelanders & 128 & 125 & $97 \cdot 66$ & $\tau_{3}$ & $\overline{0}$ & 3 & $2 \cdot 34$ & - & - & 0.9883 & $\overline{0}$ & 0.0117 \\
\hline $\begin{array}{l}\text { Pakistanis } \\
\text { Germans }\end{array}$ & $\begin{array}{l}121 \\
137\end{array}$ & $\begin{array}{l}118 \\
135\end{array}$ & $\begin{array}{l}97 \cdot 52 \\
98 \cdot 54\end{array}$ & $\begin{array}{l}3 \\
2\end{array}$ & $\begin{array}{l}2 \cdot 48 \\
1 \cdot 46\end{array}$ & E & $=$ & - & $=$ & $\begin{array}{l}0.9876 \\
0.9927\end{array}$ & $\begin{array}{l}0.0124 \\
0.0073\end{array}$ & $=$ \\
\hline $\begin{array}{l}\text { Germans } \\
\text { Greeks }\end{array}$ & $\begin{array}{l}137 \\
218\end{array}$ & $\begin{array}{l}135 \\
201\end{array}$ & $\begin{array}{l}98 \cdot 04 \\
92 \cdot 20\end{array}$ & 10 & $\begin{array}{r}1.40 \\
4.59\end{array}$ & $\overline{6}$ & $2 \cdot \overline{75}$ & $\overline{1}$ & $0 \cdot \overline{46}$ & $\begin{array}{l}0.9927 \\
0.9587\end{array}$ & $\begin{array}{l}0.0073 \\
0.0252\end{array}$ & $0 \cdot \overline{01} 61$ \\
\hline
\end{tabular}

We report an examination of six hundred and four individuals belonging to four Caucasian populations: three of European origin (Icelanders, Germans and Greeks) and one from Pakistan. The Icelanders come from the region of Dalasysla in north-west Iceland, and comprise both men and women of varying ages. Closer or further relationship between some of them cannot be excludod. The sera from Pakistan were collected from students in Peshawar (West Pakistan), most of whom were men aged between 15 and 29 years. Nearly 90 per cent of them were born in Peshawar and they were not closely related. The Greek and German sera are from healthy, adult, unrelated blood donors, most of whom were men. The Greek individuals were born in various areas of Greece. The German control group comes from Hessia.

The material was first investigated by two screening tests, the agar diffusion test $\mathrm{t}^{\hat{\theta}, 3}$ and the spectrophotometric inhibition test with $R O 2-0683$ as inhibitor according to Goedde $e t a l .{ }^{8}$. In this way, sera with a variant enzyme were discovered. The dibucaine and fluoride numbers were then determined on these samples and on all the Icelandic sera.

The carriers of the alleles for both the dibucaine-resistant and the fluoride-resistant enzymes can be identified by these methods. Altogether six phenotypes can be recognized by spectrophotometry and the remainder are assumed to be U phenotype. Four of these six phenotypes were found in our material. Table 1 shows the frequencies of the various phenotypes and the gene frequencies estimated by simple gene count. Because tho heterozygotes $E_{1} u E_{1} s$ cannot be discriminated by the screening tests used here, such sera may be included in the number of samples with $U$ phenotype, thus introducing a small error in the estimation of the frequency of the usual allele ${ }^{15}$. As Table 1 shows, the incidence of the I phenotype is highest in the Greek population (4.6 per cent); it is absent in the Icelanders, intermediate $(\mathbf{2 . 5}$ per cent) in the Pakistan population and low ( 1.5 per cent) in the German population. The UF phenotype was found only in the Icelanders and Greeks and in about the same incidence (2.3 and 2.8 per cent respectively). The populations from Iceland and Pakistan differ very slightly in the distribution and incidence of the pseudocholinesterase phenotypes (chi-square, $d . f .=2,0.05>P>0 \cdot 02$ ), and there was no difference between the other series. The frequencies of the UF phenotype in the four populations fall within the range of the few comparable data yet available; these are Germans (Baden) 1.5 per cent ${ }^{8}$, Brazilians 0.93 per cent ${ }^{15}$ and Japanese $2 \cdot 0$ per cent ${ }^{14}$. The frequencies of the usual and atypical heterozygotes from Germany and Greece do not differ significantly from the data reported by other
This work was supported by the Deutsche Forschungsgemeinschaft. We thank all those who have helped with the collection of samples: Dr J. Pálsson, Reykjavik, who supplied the Icelandic material, Dr W. Bernhard, Institute of Anthropology, University of Mainz, who sent the Pakistan samples, and C. Yannissis, Athens, who prepared and transported the Greek sera.

\section{SiegFried NeumanN} HUBERT WaLter

Section of Human Genetics,

Institute of Anthropology,

University of Mainz,

Germany.

Received May 22; revised June 17, 1968.

Motulsky, A. G., in Progress in Medical Genetics (edit, by Steinberg, A., and Bearn, A. 3, 49 (Grume and Stratton, New York, 1964)

${ }^{2}$ Kalow, W., and Gencst, K., Canad. J. Biochem. Physiol., 35, 339 (1957). ${ }^{3}$ Kalow, W., and Staron, N., Canad. J. Biochem. Physiol., 35, 1305 (1957).

${ }^{4}$ Harris, H., and Whittaker, M., Nature, 191, 496 (1961).

- Liddell, J., Lehmann, H., and Silk, E., Nature, 198, 561 (1962).

' Harris, H., and Robson, E. B., Lancet, ii, 218 (1963).

"Goedde, H. W., and Fuss, W., Klin. Wschr., 42, 286 (1964).

Goedde, H. W., Omoto, K., Ritter, H., and Baitsch, H., Humangenetik, 1, 1 (1964).

Kattamis, C., Zannos-Mariolea, T., Franco, A. P., Liddell, H., Lehmann, H. and Davies, D., Nature, 186, 599 (1962).

${ }^{\circ}$ Altland, K., Epple, F., and Goedde, H. W Humangsnetik, 4, 127 (1967).

${ }^{11}$ Motulsky, A. G., and Morrow, A., Science, 159, 202 (1968).

${ }^{12}$ Horsfall, W. R., Lehmann, H., and Davies, D., Nature, 199, 1115 (1963).

${ }^{13}$ Lisker, R., Del Moral, C., and Loria, A., Nature, 202, 815 (1964).

${ }^{14}$ Omoto, K., and Goedde, H. W., Nature, 205, 726 (1965).

${ }^{13}$ Simpson, N. E., and Kalow, W., Amer. J. Human Genet., 17, 156 (1965).

18 Gutsche, B. B., Scott, E. M., and Wright, R. C., Nature, 215, 322 (1967).

\section{Pigment Studies on Several Eye-colour Mutants of the Honey Bee, Apis mellifera}

ANalyses of eye-colour mutants have brought important contributions to the genetics, as well as to the biochemistry, of pigment metabolism of insects ${ }^{1}$. As in Drosophila, Ephestia and Bombyx, mutants have been found in Apis mellifera which are more or less different in their eye colour ${ }^{2,3}$. Although several genetic studies have been carried out on these honey bee mutations ${ }^{3,4}$, their characteristic phenotypes have not been analysed chemically. The objective of the research reported here was to identify the substances producing the eye colour of the mutants and to follow every change in their metabolism so that all mutants could be chemically characterized. 